\title{
POLÍTICAS PÚBLICAS EDUCACIONAIS
}

PARA IMIGRANTES E REFUGIADOS: REDE DE ACOLHIMENTO NO RIO GRANDE NO SUL

Danielle Busko

EDUCATIONAL POLICIES FOR IMMIGRANTS AND REFUGEES: WELCOME NETWORK IN RIO GRANDE DO SUL 


\title{
POLÍTICAS PÚBLICAS EDUCACIONAIS PARA IMIGRANTES E REFUGIADOS: REDE DE ACOLHIMENTO NO RIO GRANDE DO SUL
}

\author{
EDUCATIONAL POLICIES FOR IMMIGRANTS AND REFUGEES: WELCOME NETWORK IN RIO
}

GRANDE DO SUL

Danielle Busko

Administradora com habilitação em Comércio Exterior e Técnica em Assuntos Educacionais da Defensoria Pública da União em Porto Alegre. Rio Grande do Sul, Brasil.

danielle.busko@dpu.def.br

\section{RESUMO}

O objetivo desse artigo é analisar o tema dos imigrantes e refugiados como um desafio para as políticas públicas educacionais, considerando que estas podem ser ferramentas para minimizar a discriminação e apoiar a inserção social. Após a introdução, apresentase um mapeamento da realidade dos imigrantes no Brasil e, de forma mais detalhada, no Rio Grande do Sul, delineando o seu perfil. Aborda-se, entâo, dois enfoques distintos, porém complementares: políticas públicas educacionais integrativas e educação para a cidadania e inclusão. Ademais faz-se consideraçóes sobre o papel da Defensoria Pública da União na Educação em Direitos voltada ao empoderamento do imigrante e do refugiado como fator definitivo para o seu real acolhimento. Nas consideraçốes finais destacou-se a relevância do capital social e cultural dos migrantes como gerador de novos valores para o contexto que o acolhe.

Palavras-chave: Políticas Públicas. Educação. Imigrantes. Refugiados. Rio Grande do Sul. 


\begin{abstract}
The purpose of this article is to analyze the issue of immigrants and refugees as a challenge for public educational policies, considering that these can be tools to minimize discrimination and support social integration. After the introduction, we present a mapping of the reality of immigrants in Brazil and, in a more detailed way, in the state of Rio Grande do Sul, and outline their profile. Then, we address two distinct but complementary approaches: integrative public education policies and education for citizenship and inclusion. In addition, we make considerations about the role of the Public Defender of the Union in the Rights Education aimed at the empowerment of the immigrant and the refugee as a definitive factor for their real reception. In the final considerations, we underline the relevance of the migrants' social and cultural capital as generator of new values for the context that welcomes them.
\end{abstract}

Keywords: Public Policies. Education. Immigrants. Refugees. Rio Grande do Sul.

Data de submissão: 21/03/2017

Data de aceitação: 04/08/2017

\title{
SUMÁRIO
}

INTRODUÇÃO 1. FLUXO HISTÓRICO DE IMIGRANTES NO BRASIL 2. POLÍTICAS PÚBLICAS EDUCACIONAIS INTEGRATIVAS 3. EDUCAÇÃO PARA A CIDADANIA E INCLUSÃO 3.1 O papel da Defensoria Pública da União na Educação em Direitos, voltada ao empoderamento do imigrante e do refugiado como fator definitivo para o seu real acolhimento. CONSIDERAÇÓES FINAIS. 


\section{INTRODUÇÁO}

O tema das políticas públicas educacionais é um assunto abrangente e inter-disciplinar, além de multicultural, quando abordado sob a ótica do ser humano que tem a coragem de empreender em outro país, como no caso dos imigrantes, ou que é forçado a realizar esta empreitada, como no caso dos refugiados e suas famílias. Muitas barreiras devem ser superadas para que estas pessoas obtenham sucesso e sintam-se integradas nesta nova sociedade. A primeira delas é, sem dúvida, o aprendizado da língua portuguesa, assim como o conhecimento das leis e da cultura da sociedade acolhedora. Desta forma, é possível questionar: existem políticas públicas educacionais que atuem especificamente junto aos imigrantes e aos refugiados? Em função da grande importância deste tema para a vida dos crescentes grupos no Brasil, este trabalho tem por objetivo contribuir para mapear a rede de acolhida no estado do Rio Grande do Sul, através de coleta de dados e entrevistas com representantes de instituiçôes governamentais, associaçôes e organizaçóes da sociedade civil, no sentido de verificar como se dá o acolhimento, principalmente no que diz respeito à educação.

Destarte, o trabalho visa fornecer subsídios para que se formulem políticas públicas educacionais que tenham por meta, não somente o ensino de português para estrangeiros, mas o empoderamento destes trabalhadores, através do desenvolvimento de açóes voltadas à conscientizaçáo de seus direitos e à valorizaçáo do patrimônio cultural de que são possuidores.

\section{FLUXO HISTÓRICO DE IMIGRANTES NO BRASIL}

Fluxos migratórios fazem parte da formação do povo brasileiro. Além do grande fluxo de negros africanos que vieram para o Brasil, como escravos, merecem destaque os fluxos de açorianos, italianos, alemáes, poloneses, japoneses e sírios que, com sua cultura e força de trabalho, vieram a contribuir para a construção da história do povo brasileiro em diferentes regióes do país. Tanto no passado, quanto nos dias atuais, os que imigram e se refugiam costumam estar fugindo de problemas econômicos, guerras ou de ameaças perpetradas por regimes autoritários em seus países de origem, como as ditaduras, o comunismo, o nazismo e o fascismo. Foi à formação da comunidade multicultural brasileira que, ao longo do tempo, contribuiu para divulgar a crença de que a sociedade brasileira é formada 
por um povo acolhedor e aberto para a recepção de imigrantes.

Para uma contextualização, é detalhado na tabela 1 , o fluxo histórico de imigrantes no Brasil entre 1500 e 2014, bem como, os fatores que estimularam a imigração e os diversos povos que se deslocaram para o país.

Tabela 1: Fluxo Histórico de Imigrantes no Brasil

\begin{tabular}{|c|c|c|}
\hline Período & Fatores que estimularam a imigração & Etnias e Nacionalidades \\
\hline $1500-1747$ & Descoberta e início da colonização. & $\begin{array}{l}\text { Habitantes milenares, donos das } \\
\text { capitanias hereditárias - europeus } \\
\text { e africanos advindos da imigraçáo } \\
\text { forcada. }\end{array}$ \\
\hline $1747-1820$ & $\begin{array}{l}\text { Extinção das Capitanias Hereditárias, dando início à imigração } \\
\text { de açorianos. }\end{array}$ & $\begin{array}{l}\text { forcada. } \\
\text { Portugueses advindos das ilhas dos } \\
\text { Açores. }\end{array}$ \\
\hline $1812-1870$ & $\begin{array}{l}\text { Após a proclamaçáo da República, o Decreto } \mathrm{n}^{\circ} 528 / 1890 \\
\text { regulamenta e autoriza a formação de colônias formadas } \\
\text { por imigrantes de países estrangeiros, desde que aptos para o } \\
\text { trabalho e com aptidão para trabalhos em qualquer indústria. }{ }^{1}\end{array}$ & $\begin{array}{l}\text { Inglesa, suíça, francesa, alemã, italiana, } \\
\text { polonesa, russo-ucraniana, turca, } \\
\text { libanesa, austríaca e lituana. }\end{array}$ \\
\hline $1870-1959$ & $\begin{array}{l}\text { Guerras nos continentes europeus, asiáticos e no Oriente } \\
\text { Médio, geram um fluxo imigratório constante para todo o país. } \\
\text { Embora tenha havido um regime de cotas para imigraçấo, em } \\
\text { 1934, reforçado pela CF de } 1937^{2} \text {, no pós-guerra, houve uma } \\
\text { flexibilizaça.o. }\end{array}$ & $\begin{array}{l}\text { Primeiramente europeus e } \\
\text { posteriormente, asiáticos. }\end{array}$ \\
\hline 1960-1999 & $\begin{array}{l}\text { Presença de ditaduras militares nos países latino-americanos e } \\
\text { o processo de independência das colônias na África ocasionam } \\
\text { o crescimento da imigração de pessoas dos países latinos e } \\
\text { africanos, unida à necessidade de obter mão-de-obra para o } \\
\text { "milagre econômico" brasileiro. Declaraçáo de Cartagena de } \\
1984 \text {. }\end{array}$ & $\begin{array}{l}\text { Uruguaia, argentina, peruana, } \\
\text { paraguaia, angolana, moçambicana, } \\
\text { coreana e egípcia. }\end{array}$ \\
\hline $2000-2014$ & $\begin{array}{l}\text { Conseqüências da crise financeira do capitalismo norte- } \\
\text { americano. Crises em países da América Latina: má distribuição } \\
\text { de renda, desastres naturais, além de impactos do narcotráfico. } \\
\text { Conflitos tribais internos, guerras religiosas e violaçâo dos } \\
\text { direitos humanos na África. Desastres ambientais e conflitos } \\
\text { internos raciais no Caribe. Assinatura de acordos com os países } \\
\text { do Mercosul e da África, bem como o Acordo de Cooperação } \\
\text { com o Haiti. }\end{array}$ & $\begin{array}{l}\text { Acréscimo de colombianos e } \\
\text { mexicanos, portugueses, espanhóis, } \\
\text { italianos e franceses, somando-se } \\
\text { aos africanos, caribenhos, latinos e } \\
\text { asiáticos. }\end{array}$ \\
\hline
\end{tabular}

FONTE: ZAMBERLAM (2014). ${ }^{1}$

Em razáo da necessidade de acolhimento dos refugiados provenientes das guerras mundiais, no período entre 1870 e 1959, é elaborada a Convenção de Genebra Relativa ao Estatuto dos Refugiados, que forja o conceito de refugiado como aquele que possui fundado temor de perseguição por razóes de raça, religião, nacionalidade, filiação em certo grupo social ou opiniôes políticas. E, como consequência, é reconhecido o direito do indivíduo perseguido em seu país de origem, de transpor fronteiras para buscar asilo e, solicitar proteção em um segundo país.

1 Dados tabulados pela autora com base nas informaçôes de ZAMBERLAM, J., et al. Os novos rostos da imigraçáo no Brasil: haitianos no Rio Grande do Sul,2014, pp. 09-14. 
Destarte, é na Declaração de Cartagena, em 1984, que ficam expressos os desdobramentos dos debates sobre Direitos Humanos ocorridos no século XX e os compromissos que os estados nacionais deveriam ter com a população de refugiados internacionais. A declaração faz parte da trajetória dos direitos humanos na América Latina, do compromisso com seus princípios e de uma adesão efetiva, prevista constitucionalmente nos tratados e protocolos relativos ao refúgio. De qualquer maneira, o conhecimento do estatuto do refúgio não exaure todos os aspectos sobre a questão, pois este não é um tema exclusivamente jurídico, abrangendo vários aspectos e setores da sociedade e expondo algumas lacunas nas proteções e compromissos públicos assumidos pelo Estado, como será visto em tópicos posteriores.

Diferentemente dos imigrantes que, de livre vontade e com espírito empreendedor, se preparam com antecedência para realizar um projeto de vida em um país estrangeiro com a perspectiva de encontrar melhores oportunidades para prosperar, pode-se caracterizar os refugiados como imigrantes forçados, que cruzam as fronteiras nacionais de seus países de origem de maneira abrupta, em busca de proteçấo. A fuga de conflitos internos, internacionais ou regionais, perseguiçóes em decorrência de regimes políticos repressivos, questôes éticas, culturais e religiosas, entre outras violaçôes dos direitos humanos, muitas vezes separa famílias, causa doenças e traumas psicológicos, dificultando o processo de adaptação ao novo contexto.

Segundo o relatório Tendências Globais, lançado em junho de 2016 pelo Alto Comissariado das Naçôes Unidas (ACNUR) ${ }^{2}$, 65,5 milhóes de pessoas foram deslocadas por guerras e conflitos somente no ano de 2015. Este número representa um aumento de quase $10 \%$ se comparado com o total de 59,5 milhôes de pessoas deslocadas, registradas em 2014. Este total inclui 3,2 milhóes de pessoas em países industrializados que, ao final de 2015, encontravam-se aguardando o resultado de suas solicitaçôes. Este foi o maior número já registrado pelo ACNUR, além de 21,3 milhóes de refugiados ao redor do mundo, e ainda, as pessoas em deslocamentos internos. Se comparado com a população mundial de 7 bilhões e 349 milhôes de pessoas, estes números significam que uma a cada 113 pessoas é hoje ${ }^{3}$ solicitante de refúgio, deslocado interno ou refugiado, perfazendo uma população maior do que a existente no Reino Unido, França ou Itália.

$2 \quad$ Os dados estatísticos, podem ser observados no sítio eletrônico Oficial da ANCUR. Tendências Globais. 2016. Disponível em: < http://www.unhcr.org/576408cd7>. Acesso em: 23 mar. 2017.

3 Os dados estatísticos, podem ser observados no sítio eletrônico oficial da ANCUR. Disponível em: <http://www.acnur.org/portugues/noticias/noticia/deslocamento-forcado-atinge-recorde-global-e-afetauma-em-cada-113-pessoas-no-mundo/>. Acesso em 20 mar. 2017. 
Como reflexo da situação mundial o número de refugiados e de imigrantes que buscam oportunidade de trabalho no Brasil é cada vez maior. Segundo o Comitê Nacional para os Refugiados (CONARE) ${ }^{4}$, órgão do Ministério da Justiça, as solicitaçôes de refúgio para o país cresceram de 966, em 2010, para 28.670, em 2015, gerando um aumento de $2.868 \%$. Este desenvolvimento crescente de solicitaçôes ocasionou um acréscimo de $127 \%$ no número total de refugiados reconhecidos no Brasil entre 2010 e 2016, ou seja, aumento de 127\%, passando de 3.904, em 2010, para 8.863, em 2016.

Portanto, o CONARE contabiliza o total de 8,4 mil refugiados legalizados, incluindo os reassentados, oriundos de 79 países distintos. Os sírios são a maior comunidade de refugiados reconhecidos no Brasil, visto que somam 2.298 pessoas, seguidos dos angolanos com 1.420, dos colombianos com 1.100, dos 968 congoleses e dos 376 palestinos. Deste total, $71,8 \%$ são homens e, $78,8 \%$ encontram-se na faixa economicamente ativa, entre 18 a 59 anos. As cinco nacionalidades com maior número de solicitantes ao refúgio são haitianos, senegaleses, sírios, bengaleses e nigerianos.

No que diz respeito ao mercado de trabalho e com base nos dados de 2014, fornecidos pela pesquisadora Iracema Castelo Branco, da Fundação de Economia e Estatística no Rio Grande do Sul (FEE), ${ }^{5}$ pode-se dividir o fenômeno migratório em dois grupos: o primeiro pode ser chamado de fluxo regular e depende do nível de atividade econômica que, de certa forma, corresponde à demanda interna por profissionais estrangeiros. $\mathrm{O}$ segundo fluxo migratório representa a expectativa estrangeira de crescimento no movimento de ampliação da economia brasileira e de seus benefícios sociais. Sáo pessoas que chegam para se estabelecer no Brasil em busca de uma oportunidade de trabalho, pelo desejo de melhorar suas condiçóes de vida.

De acordo com a Coordenação Geral de Imigração (CGIg) ${ }^{6}$, órgão que integra o Ministério do Trabalho e Previdência Social, foram concedidas 36.868 autorizações de trabalho estrangeiro em 2015 e 28.658 em 2016.

\footnotetext{
$4 \quad$ O relatório do CONARE, com os dados estatísticos e as porcentagens, pode ser acessado no sítio eletrônico oficial: <http://csem.org.br/index.php/estatisticas/4635-sistema-de-refugio-brasileiro>. Acesso em: 15 mar. 2017

5 BLANCO, Iracema Castelo. Os novos trabalhadores imigrantes: o sonho brasileiro. FEE. Disponível em: <http://panoramainternacional.fee.tche.br/article/os-novos-trabalhadores-imigrantes-osonho-brasileiro/>. Acesso em 10 mar. 2017.

6 As estatísticas relativas ao Ministério do Trabalho e Previdência Social estão disponíveis em: Autorizaçóes de trabalho concedidas a estrangeiros: relatório anual 2015-2016, 2017, pp. 10-22.
} 
Das autorizaçôes relativas ao ano de 2016, 25.393 foram para homens e 3.265 para mulheres - sendo que $39 \%$ tem de 20 a 34 anos e $41 \%$ apresenta idade entre 35 e 49 anos e, deste total, $56 \%$ tem curso superior completo. Ainda no que diz respeito as autorizações de 2016, 1.360 são em caráter permanente e 27.298 em caráter temporário; em relação ao prazo das concessốes temporárias, 8.449 autorizaçôes foram por até 90 dias, 4.335 por até um ano.

Em relação ao país de origem, o Haiti deteve 63,4\% das autorizaçôes do Conselho Nacional de Imigração $(C N I g)$, que é a instância de articulação da Política Migratória Brasileira, em especial da Política de Migraçáo Laboral, restando ainda cerca de 40.000 processos de haitianos para análise. O fluxo de haitianos para o Brasil deu-se em 2004, através de acordos de cooperação técnica e científica entre o governo brasileiro e o haitiano, quando teve início a presença brasileira no Haiti, após o terremoto de 2010.

Os imigrantes haitianos eram os únicos que possuíam visto permanente por razóes humanitárias, porém, em fevereiro de 2017, por pressão da Defensoria Pública da União, entre outros órgãos, este tipo de visto foi estendido aos venezuelanos ${ }^{7}$, em razão do aprofundamento da crise econômica e de escassez de alimentos na Venezuela.

Ainda segundo o $\mathrm{CNIg}^{8}$, no período de 2010 a 2014, foram registrados 34.887 pedidos de refúgio por haitianos, sendo que $83 \%$ ocorreram nos últimos dois anos, o que indica que esse fluxo é recente e ainda tende a crescer. A República do Haiti possui 10,3 milhóes de habitantes, sendo que $80 \%$ vivem na extrema pobreza, com uma renda de 1,25 dólar ao dia e, além da situação econômica, o país enfrenta desafios ambientais e graves desigualdades sociais.

A principal rota usada para chegar ao Brasil compreende vôos de Porto Príncipe a Quito, no Equador, seguindo por via terrestre, passando pelo Peru até chegar ao Brasil, no estado do Acre, e daí dirigindo-se para outras regiôes em busca de trabalho.

Com base na Relação Anual de Informaçóes Social (RAIS), pesquisada pelo Ministério

\footnotetext{
7 Informaçóes sobre este tema podem ser observados no sítio eletrônico oficial da DPU: <http:// www.dpu.def.br/noticias-defensoria-publica-da-uniao/68-noticias-internacional/35840-cnig-adotarecomendacao-da-dpu-e-autoriza-residencia-para-venezuelanos>. Acesso em: 24 mar. 2017.

8 Dados estatísticos disponíveis sobre o Conselho Nacional de Imigração (CNIg) em: <http:// trabalho.gov.br/dados-abertos/trabalho-estrangeiro/estatisticas-imigracao/conselho-nacional-de-imigracaocnig>. Acesso em: 18 mar. 2017.
} 
do Trabalho e Previdência Social ${ }^{9}$, o Haiti possui o maior contingente de trabalhadores formais no Brasil, tendo ultrapassado Portugal, que esteve na liderança entre 2010 e 2012. O número de imigrantes com carteira assinada apresentou um crescimento de 107,5\% entre 2010 e 2014, chegando a 34.773 no ano de 2015.

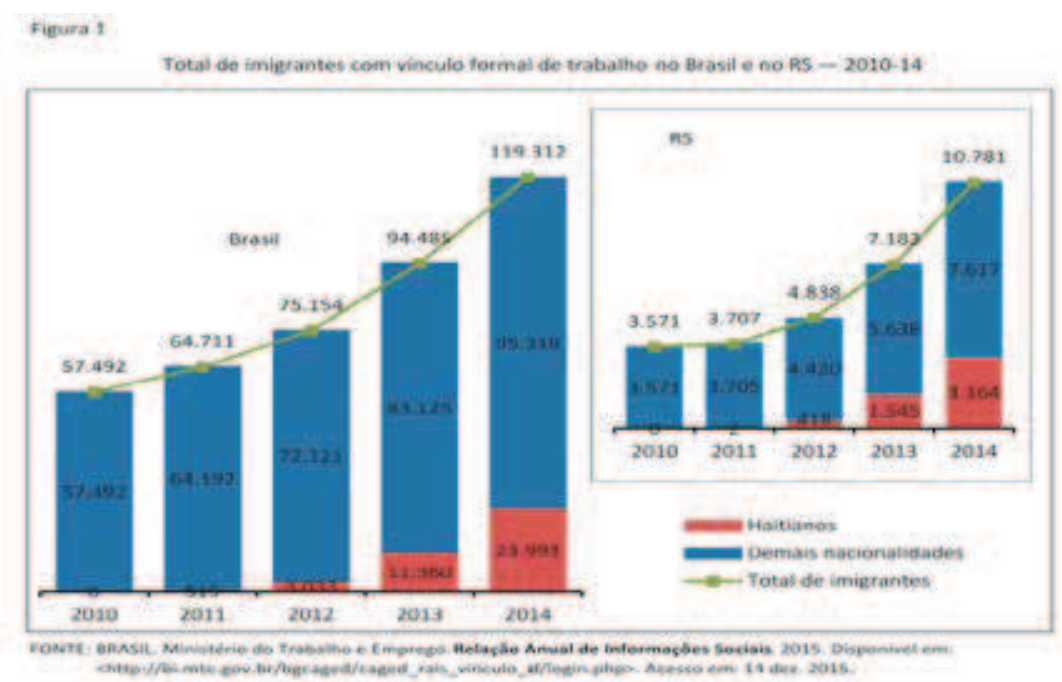

A Figura 1 demonstra que, em relação ao país de origem, os três países primeiros colocados são o Haiti, com 20,1\% com um total de 23.993 pessoas; Portugal, com 9,0\%, com um total de 10.770 pessoas; e Argentina, com 6,6\% cujo total é de 7.832 pessoas. Este conjunto de pessoas é composto por $73,2 \%$ de homens e $26,8 \%$ de mulheres, representando o total de imigrantes com vínculo formal no Brasil e no Rio Grande do Sul.

Destaca-se ainda que os imigrantes haitianos são mais jovens (83\%), tendo menos de 39 anos e sendo menos escolarizados do que os demais imigrantes com vínculo formal de trabalho, com somente $2,7 \%$ de haitianos com curso superior completo, conforme demonstra a Figura 2.

9 Dados estatísticos disponíveis em: <http://obmigra.mte.gov.br/index.php/relatorios-cgig-e-cnig>. Acesso em 10 jan. 2017. 


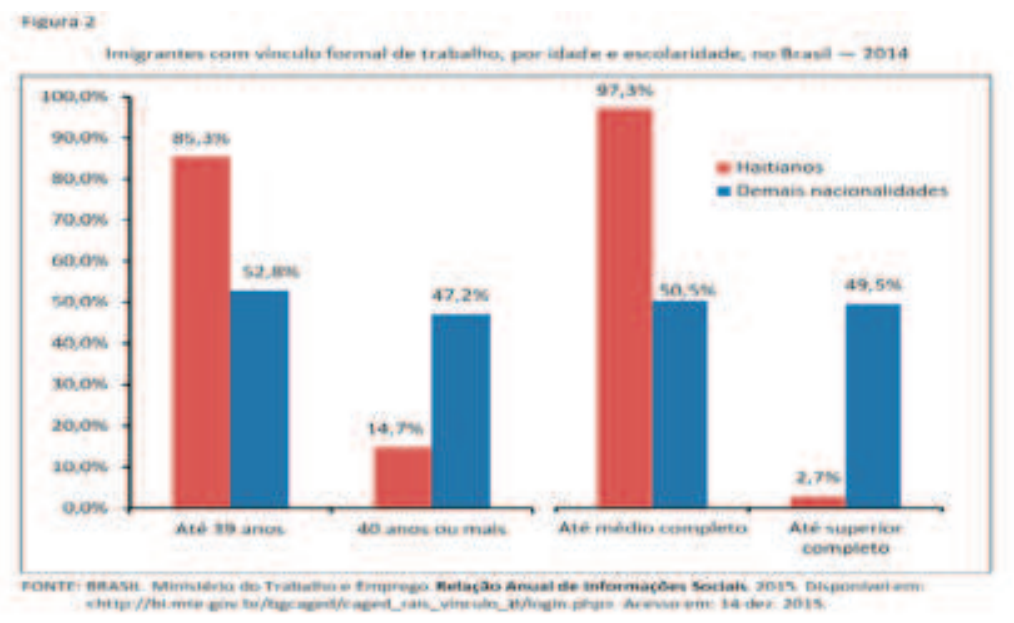

Ainda segundo o Ministério do Trabalho e Previdência Social ${ }^{10}$, o Rio Grande do Sul está entre os principais destinos de quem chega ao Brasil com a intenção de imigrar, sendo que, em 2016, a maioria das autorizaçóes de trabalho se concentrou no Rio de Janeiro (43\%), Sáo Paulo (39\%), Rio Grande do Sul (2\%) e Paraná (2\%).

Se observarmos o comportamento dos fluxos imigratórios no Rio Grande do Sul, vamos verificar que entre os anos de 2000 a 2014, existem pontos de crescimento bem significativos nos somatórios anuais, que se apresentam no aumento de 198,8\% entre 2000 e 2010 e, paralelamente, de mais 125\% entre 2010 e 2014.

Estes movimentos representam uma evolução muito maior do que o esperado para a tendência nacional, cuja previsão era em torno de 15 mil imigrantes para o período de 15 anos. De tal modo que, entre 2007 e 2014, o estoque total de imigração no estado chegou a 84 mil imigrantes, o que representa $0,8 \%$ da população do Rio Grande do Sul, conforme menciona o pesquisador Roberto Uebel. ${ }^{11}$

Estes números ficam mais significativos se analisarmos que o número de imigrantes no Rio Grande do Sul cresceu, somente nos quatro últimos anos, o mesmo que em toda a década de 2000-2010, segundo análise dos dados da Tabela 2 e Gráfico 1, que demonstram esta evolução.

10 Trabalho e Previdência Social estão disponíveis em: Autorizaçóes de trabalho concedidas a estrangeiros: relatório anual 2015-2016, 2017, p.14.

11 UEBEL, R. Análise do perfil socioespacial das migraçóes para o RS no início do século XXI: redes, atores e cenários da imigração haitiana e senegalesa, 2015, pp. 227-230. 
Tabela 2 - Crescimento de imigrantes no Rio Grande do Sul

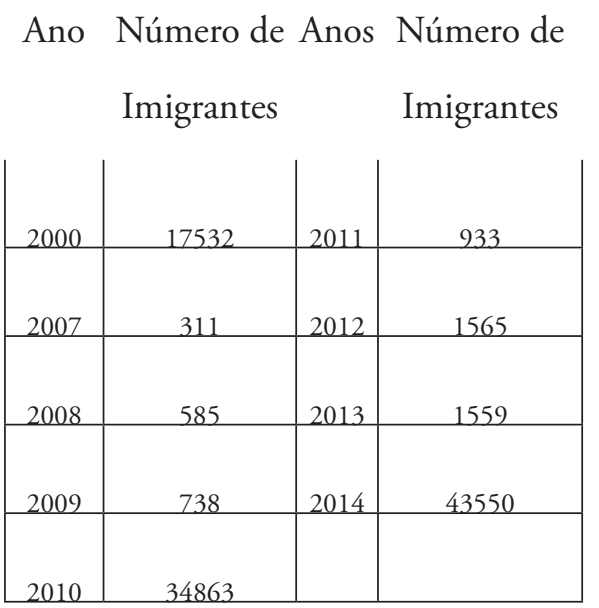

Crescimento de imigrantes no Rio Grande do Sul - estoque total de 2000 a 2014

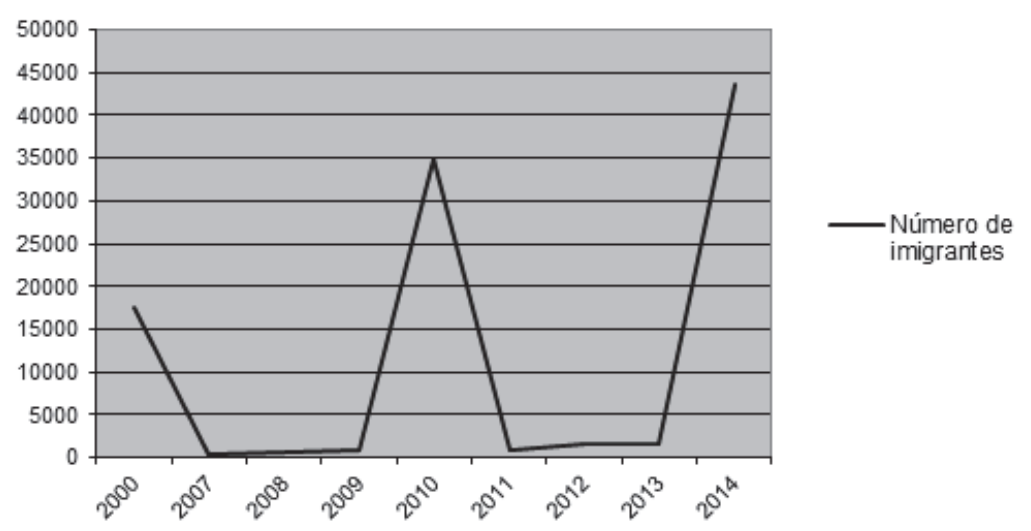

Fonte: Gráfico 1, com base nos dados compilados por UEBEL. ${ }^{12}$

12 UEBEL, R. Análise do perfil socioespacial das migraçóes para o RS no início do século XXI: redes, atores e cenários da imigração haitiana e senegalesa, 2015, p. 117. 
Conforme entrevista realizada com Eliani de Oliveira, secretária executiva do Centro Ítalo -Brasileiro de Assistência e Instrução às Migrações (CIBAI) ${ }^{13}$, em 2015, o estado gaúcho contava com imigrantes e refugiados distribuídos entre 100 municípios. A maior parte está localizada nas cidades serranas como Caxias do Sul, que conta com mais de 2 mil pessoas e Bento Gonçalves, com 1,3 mil imigrantes. A região de Passo Fundo abriga em torno de mil e duzentas pessoas, o mesmo acontecendo com Lajeado e Porto Alegre.

Em consequência do aumento no fluxo migratório para o Rio Grande do Sul, ocorreu um crescimento de mais de $300 \%$ no montante de mão de obra imigrante com carteira assinada, passando de 3.571, em 2010, para 10.781, em 2014, conforme dados da RAIS.

O CIBAI, que atende gratuitamente aos imigrantes de todas as nacionalidades em Porto Alegre, estima que entre 2010 e 2014, mais de 5 mil africanos pediram refúgio, especialmente somalis, senegaleses, ganeses, cabo-verdianos e moçambicanos sendo que a maioria fixou residência nos três estados do sul do Brasil em razão da localização das indústrias avícolas que são exportadoras de carne com selo Halal para países seguidores da religião islâmica.

O abate Halal é o modo pelo qual os animais devem ser mortos de forma ritualística realizado por muçulmanos mentalmente sadios e conhecedores das regras. Entre as exigências, existem frases específicas que devem ser ditas, equipamentos e utensílios próprios para o Halal.

Grande parte das imigraçóes africanas ocorreram nas últimas décadas do século XX, em razão dos vários conflitos pela independência, das secas prolongadas e dos Acordos de Cooperação entre o Brasil e países da África.

O Gráfico 2 e a Tabela 3, demonstram a participação, por nacionalidade, dos imigrantes africanos no Rio Grande do Sul em 2014, onde se pode notar a expressiva participação dos senegaleses, com $67,01 \%$, seguidos dos marroquinos com 7,6\% e dos ganeses com $6,30 \%$.

O caso dos angolanos, nigerianos e sul-africanos está pautado por uma situação distinta àquela dos imigrantes da costa oeste africana ou dos refugiados e migrantes internos,

13 Para a produção do artigo, foi realizada entrevista com Eliane de Oliveira, secretária do setor de imigração, sobre a atuação do CIBAI Migraçôes nos casos de imigrantes no Rio Grande do Sul. Porto Alegre, 03 mar. 2017. Informação verbal. 
como os ganeses, já que possuem um perfil social, laboral e econômico distinto, visto que estas três nacionalidades de imigrantes estão inseridas no contexto de: intercambistas em centros de ensino superior, missionários de igrejas e, em menor parte, trabalhadores da construçáo civil e setor naval. Os imigrantes deste grupo vieram para o Rio Grande do Sul com uma proposta de emprego ou atuaçáo profissional consolidada, caracterizando-se uma imigração específica, demandada e, por vezes, temporária.

Gráfico 2 e Tabela 3 - Imigraçóes Africanas do RS

\begin{tabular}{|l|l|l|l|}
\hline Nacionalidade & BRASIL & RS & \% \\
\hline Senegaleses & 970 & 650 & 67,01 \\
\hline Marroquinos & 697 & 53 & 7,60 \\
\hline Ganeses & 397 & 25 & 6,30 \\
\hline Cabo-verdianos & 4.446 & 197 & 4,43 \\
\hline Guieeses & 2.913 & 104 & 3,57 \\
\hline Angolanos & 11.028 & 294 & 2,66 \\
\hline Egípcios & 1.233 & 27 & 2,19 \\
\hline Nigerianos & 3.132 & 53 & 1,69 \\
\hline Demais países & 7.545 & 610 & 8,08 \\
\hline Total & 32.270 & 2.013 & \\
\hline
\end{tabular}

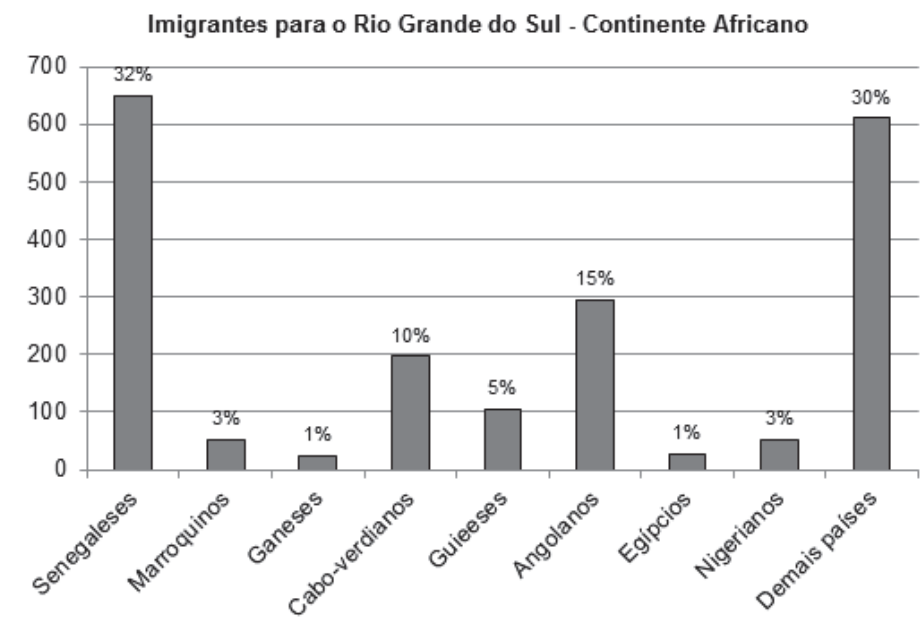

Fonte: Dados tabulados com base nas informações de ZAMBERLAM (2014).

Já as imigrações provenientes do continente americano, sofrem grande influência da proximidade geográfica. Deste modo, existe um considerável número de uruguaios 
e argentinos no Rio Grande do Sul, o que se justifica pela atratividade econômica, similaridade cultural e lingüística.

No entanto, este processo não justifica os deslocamentos populacionais de longa distância, como colombianos e haitianos, conforme podemos notar na Tabela 3 e no Gráfico 2, que demonstram as imigraçóes do continente americano para o Rio Grande do Sul.

Gráfico 3 - Imigrações do Continente Americano no RS

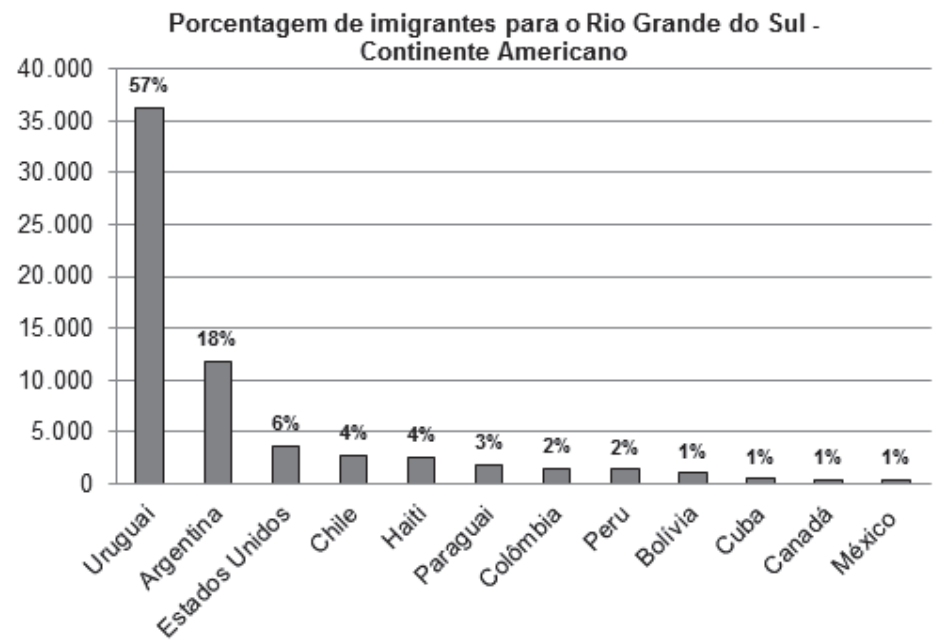

Fonte: Gráfico realizado com base nos dados compilados por Uebel (2015). ${ }^{14}$

Para elucidar este tema, destacamos o resultado da pesquisa de Uebel:

Assim, o que caracteriza este aumento e presença expressiva de colombianos no território sul-rio-grandense está majoritariamente ligado ao status de refúgio obtidos por estes, nâo sendo caracterizados, portanto, imigrantes econômicos. Já os haitianos são predominantemente motivados pela atratividade laboral e econômica do estado, coincidente com o aumento do número de vagas registrado pela indústria e comércio rio-grandense no mesmo período bem como pela inserção estratégica do Brasil no Haiti. (...) Por fim, os imigrantes de nacionalidade boliviana e paraguaia não possuem representatividade considerável no cenário imigratório do Rio Grande do sul em virtude de que estes preferem imigrar para os estados fronteiriços aos seus países, como Mato Grosso, Mato Grosso do Sul e São Paulo (...), cada estado brasileiro tem nas suas principais composiçôes (e

14 UEBEL, R. Análise do perfil socioespacial das migraçóes para o RS no início do século XXI: redes, atores e cenários da imigração haitiana e senegalesa, 2015, pp. 227-ss. 
rankings) imigrantes de países vizinhos: uruguaios e argentinos no Rio Grande do Sul, bolivianos e paraguaios no Mato Grosso, peruanos e bolivianos no Acre, etc. Já a participação dos imigrantes de origem européia nos cenários do estado neste biênio de 2013-2014 segue em certa medida o padrão da escala brasileira.

As imigraçóes advindas do continente europeu seguem os fluxos de crescimento na imigração brasileira, onde os imigrantes de origem portuguesa, espanhola e italiana ainda possuem uma forte representação na composição do perfil imigratório do Rio Grande do Sul. Ressalta-se ainda outros fluxos vindos da Europa para os estados do sul do Brasil, devido às outras distintas redes de colonização histórica, como a forte presença de imigrantes alemães, poloneses e holandeses em uma proporção maior que a verificada no restante do país.

A aproximação cultural se mostra efetiva e mantida ao longo dos últimos 180 anos, prevalecendo assim, a hipótese de que existem redes migratórias históricas que são o principal aporte e esteio para as atuais migraçóes internacionais. Considerando a crise econômica e de emprego persistente no continente europeu em função da desvalorização da moeda, houve o estimulo aos fluxos migratórios em direção ao Rio Grande do Sul, estado que se caracteriza por oferecer postos de trabalho para trabalhadores especializados e comunidades de origem cultural semelhantes, coincidindo com o perfil destes imigrantes. Estes dois movimentos estão demonstrados no Gráfico 4.

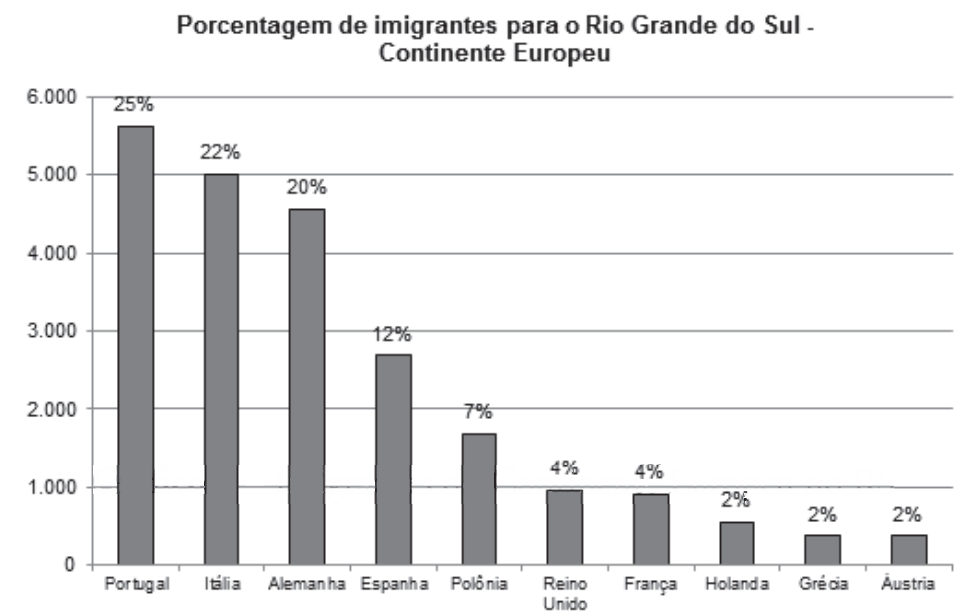

Fonte: Gráfico realizado com base nos dados compilados por UEBEL (2015). ${ }^{15}$

15 UEBEL, R. Análise do perfil socioespacial das migraçóes para o RS no início do século XXI: redes, atores e cenários da imigração haitiana e senegalesa, 2015, pp. 227-ss. 
No caso da Ásia, segundo o Gráfico 5, constata-se a presença da imigração japonesa, russa e chinesa, voltada agora para postos de trabalho especializados e imigraçóes com objetivos acadêmicos, concentrada em pólos universitários como Porto Alegre, Santa Maria e Caxias do Sul, em razão da cooperaçáo de ensino firmada entre o Brasil e os países participantes do BRICS e das parcerias empresariais do Rio Grande do Sul com empresas de tecnologia da China, Rússia e Índia, além do Japão.

\section{Gráfico 5 - Imigraçôes do Continente Asiático no RS}

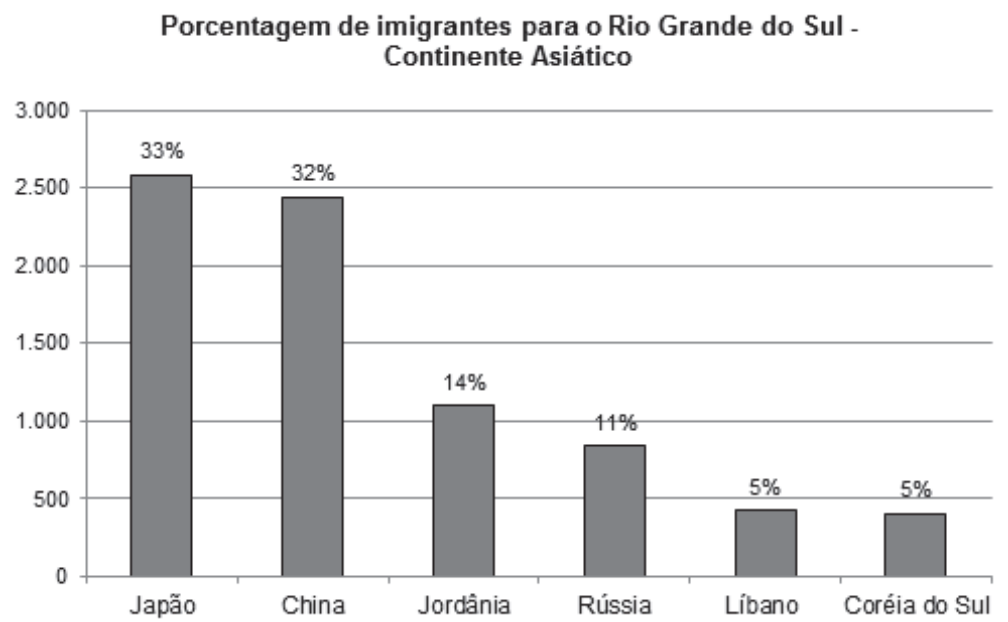

Fonte: Gráfico realizado, com base nos dados compilados por Uebel (2015). ${ }^{16}$

Os imigrantes palestinos, jordanianos e libaneses são, em sua maioria, indivíduos com status de refúgio ou com imigraçăo temporária para o Brasil e previsão de dirigirem-se ao Uruguai e ao Paraguai. Em sua maioria são residentes localizados em cidades como Canoas, Sapucaia do Sul, Novo Hamburgo e Porto Alegre, além de outras localidades mais ao sul do estado, como Santa Cruz do Sul e a cidade fronteiriça com o Uruguai, o Chuí. Geralmente, as comunidades que se encontram localizadas nestas cidades acolhem os refugiados e imigrantes com o objetivo de inserçáo em oportunidades de trabalho no comércio local.

16 UEBEL, R. Análise do perfil socioespacial das migraçóes para o RS no início do século XXI: redes, atores e cenários da imigração haitiana e senegalesa, 2015, pp. 227-ss. 


\section{POLÍTICAS PÚBLICAS EDUCACIONAIS INTEGRATIVAS}

A educação é um direito garantido pela legislação internacional e brasileira. A Convençâo Relativa ao Estatuto dos Refugiados, de 1951, estabelece que, aos solicitantes de refúgio e aos refugiados, deve-se conceder o mesmo tratamento garantido aos cidadáos nacionais no que refere à educaçáo primária.

O Pacto Internacional de Direitos Econômicos, Sociais e Culturais ${ }^{17}$ reconhece que a educação primária "deverá ser obrigatória e acessível gratuitamente a todos", a secundária "deve estar disponível de maneira geral e acessível para todos", e que a educação superior "deve estar igualmente acessível para todos com base na capacidade individual de cada um".

A lei 9.474/97, lei brasileira de refúgio, em seu artigo $n^{\circ}$. 44, reconhece o direito dos refugiados de terem acesso à educaçáo e prevê que o reconhecimento de certificados e diplomas necessários para o ingresso em instituiçôes acadêmicas, de todos os níveis, deverá ser facilitada para os refugiados, levando-se em conta as condiçôes desfavoráveis a que os mesmos estão expostos.

Os solicitantes de refúgio e refugiados, bem como os imigrantes residentes no Brasil devem, sem discriminação, ter acesso às instituiçóes públicas de ensino. Para isso, os estados e municípios também precisam remover os obstáculos práticos e administrativos que possam vir a ser um empecilho para o acesso a esse direito fundamental. Todos os solicitantes de refúgio, imigrantes e suas crianças necessitam se beneficiar de uma educação primária gratuita.

Uma vez que o exercício do direito à educação pode se tornar impossível devido à barreira linguística, o direito à educação primária gratuita aos solicitantes de refúgio deve ser coordenado com a aprendizagem da língua portuguesa.

A educação é parte vital do processo de integração local dos refugiados e imigrantes. É o meio pelo qual o homem atua na sociedade, visto que, materializada pelo trabalho, a educação e, consequentemente, a profissão exercida, acaba por definir a pessoa humana, qualificando-a para operar mudanças sociais. Neste sentido, pode-se acolher a concepção bergsoniana do homem:

17 Pacto Internacional de Direitos Econômicos, Sociais e Culturais. Disponível em: <http://www. planalto.gov.br/ccivil_03/decreto/1990-1994/d0591.htm>. Acesso em: 13 mar. 2017. 
Se pudéssemos nos despir de todo orgulho, se, para definir nossa espécie, nos ativéssemos estritamente ao que a história e a pré-história nos apresentam como a característica constante do homem e da inteligência, talvez não disséssemos: Homo sapiens, mas Homo faber. Em conclusão, a inteligência, encarada no que parece ser o seu empenho original, é a faculdade de fabricar... (grifos do original). ${ }^{18}$

Portanto, embora o ato de fabricar, em que se expressa a racionalidade, não defina completamente o homem, é por meio do trabalho que o homem se expressa e age sobre a natureza, ajustando-a às suas necessidades:

Podemos distinguir o homem dos animais pela consciência, pela religião ou por qualquer coisa que queira. Porém, o homem se diferencia propriamente dos animais a partir do momento em que começa a produzir seus meios de vida, passo este que se encontra condicionado por sua organização corporal. Ao produzir seus meios de vida, o homem produz indiretamente sua própria vida material. ${ }^{19}$

Deve-se, assim, considerar o trabalho como fundamental para os solicitantes de refúgio, refugiados e imigrantes, além de crucial para o processo de integração local. Tanto os refugiados, como os imigrantes devem ser capazes de sustentar a si e a suas famílias, especialmente quando não existe qualquer perspectiva de retorno ao país de origem. É por meio do trabalho regular que eles poderão adquirir sua autonomia. O direito ao trabalho é essencial para manutenção da dignidade, e com ela a saúde física e mental. Além disso, o trabalho auxilia a manter as capacidades intelectuais que facilitam a integraçáo local na sociedade de acolhida, ou um possível retorno ao país de origem, com segurança e dignidade.

Enquanto a assistência humanitária proporciona um alívio temporário, a dependência da ajuda, por longo prazo, pode ser desmoralizante. É importante salientar que, principalmente nos casos dos refugiados, a harmonia psicológica, foi muitas vezes rompida, gerando casos de depressão e ansiedade e, a impossibilidade de lograr a integração ao mercado de trabalho faz com que os refugiados permaneçam ociosos, o que só agrava sua angústia e frustração. Além disso, a demora na obtenção do emprego impossibilita o acesso às necessidades básicas como alimentação, habitação, educação e cuidados básicos de saúde. Tal situação pode levar os refugiados a se sentirem obrigados a voltar para seu país de origem onde existe uma grave ameaça para a sua vida, ou então, pode levá-los a se deslocar irregularmente para outro país.

18 BERGSON, H. A evoluçáo criadora. In: Cartas, conferências e outros escritos. pp. 153-205.

19 MARX, K.; ENGELS, F. La ideologia alemana, 1974. p. 467. 
O direito ao trabalho também é fundamental nas situações em que um solicitante de refúgio foi rejeitado e não pode ser transferido para fora do país devido a obstáculos jurídicos ou materiais. Se uma pessoa não pode ser transferida de um Estado e, esse mesmo Estado privar a pessoa de qualquer oportunidade razoável para a sua subsistência, impedindo que sejam atendidas suas necessidades mais básicas, isso pode equivaler a tratamento cruel, desumano e degradante.

Além da falta de familiaridade com a língua, o desconhecimento das regras trabalhistas, o preconceito por parte da comunidade local e a dificuldade na comprovaçáo da escolaridade e experiências laborais prévias, são os obstáculos seguidamente encontrados pelos refugiados.

Já os imigrantes, geralmente ingressam no país com um projeto para acesso ao mercado de trabalho, que pode se tornar real ou encontrar também obstáculos imprevistos ou que não foram avaliados antes de sua entrada.

Com o histórico de mais de 4.700 atendimentos a imigrantes, somente em 2016, o Núcleo de Estudos do CIBAI confirma que é grande o número de imigrantes que chega ao país sem dominar o idioma e que, para isso são necessários de seis meses a um ano de estudos. Em decorrência, durante este período os imigrantes atuam na informalidade, como vendedores ambulantes.

O CIBAI constatou a necessidade de uma formação auxiliar para o trabalho e para tal, no ano de 2016 foram oferecidos cursos de costura e modelagem, auxiliar de cozinha e estética. Já em 2017, está programada a formação para auxiliares de limpeza e um curso de cultura brasileira e cidadania.

No Distrito Federal, São Paulo, Rio de Janeiro e Porto Alegre, o Programa Nacional de Acesso ao Ensino Técnico e Emprego (PRONATEC) ${ }^{20}$, em 2016, começou a oferecer o curso de língua portuguesa e cultura brasileira. O curso é resultado do pacto firmado pelo Ministério da Justiça e Cidadania por meio do Comitê Nacional para os Refugiados (CONARE) com o Ministério da Educação. No primeiro ano de 2016, foram ofertadas 40 vagas pelo Instituto Federal de Brasília (IFB), 200 vagas em São Paulo, 70 vagas no Rio de Janeiro e 50 em Porto Alegre. As aulas têm por finalidade proporcionar o aprendizado da língua e da cultura brasileira, aos solicitantes de refúgio e refugiados.

20 Maiores informaçōes sobre o PRONATEC estão disponíveis em: <http://portal.mec.gov.br/ pronatec/cursos-pronatec>. Acesso em: 19 mar. 2017. 
O PRONATEC fornece, além das aulas gratuitas, um auxílio ao estudante para custear alimentação e transporte, de acordo com os critérios e valores da unidade ofertante.

Em se tratando do material didático para ensino de português, a Agência da ONU para Refugiados (ACNUR) lançou, em 2015, a cartilha: Pode entrar: português do Brasil para refugiadas e refugiado ${ }^{21}$ - que pode ser baixada gratuitamente pela internet através do site do ACNUR. A editora responsável pela cartilha, Sra. Talita Amaro de Oliveira, informa que o processo de elaboraçáo do material durou cerca de dez meses e teve como objetivo atender a uma demanda já antiga entre as entidades que acolhem refugiados no Brasil.

Ainda no que diz respeito ao ensino de português para imigrantes no Rio Grande do Sul, o CIBAI oferece um curso gratuito que funciona sem incentivo governamental para custear o transporte para as aulas. Desta maneira, o número de alunos varia, visto que na sua grande maioria, os imigrantes não têm como custear o transporte de suas casas até o local das aulas. Este trabalho é realizado por professores da rede pública que atuam como voluntários e não existe um material didático organizado para este fim. São oferecidas três turmas semanais, nas quintas e sábados pela manhã, e sábados à tarde, na sede do CIBAI em Porto Alegre.

O Instituto Federal no Rio Grande do Sul - IFRS oferece o curso: "Português como Língua Adicional"22, voltado aos refugiados e imigrantes. Com três módulos de 30 horas, sem custos, e totalmente EAD via sua estrutura Moodle, o curso apresenta o básico da língua portuguesa para aqueles que não podem se deslocar, mas tem acesso a um computador.

Em nível de educação superior, a Universidade Federal de Santa Maria (UFSM) 23 lançou, por meio de edital, um programa de acesso à formação técnica, tecnológica e superior voltado para esse público, em que $5 \%$ das vagas serão direcionadas para estudantes imigrantes e refugiados a partir do primeiro semestre letivo de 2017.

Serão admitidos imigrantes ou refugiados que tenham concluído o ensino médio ou

21 É possível obter o acesso a cartilha em: <http://www.acnur.org/portugues/recursos/publicacoes/>. Acesso 20 mar. 2017.

22 É possível o acesso ao Curso de português como língua estrangeira em: <https://moodle.ifrs.edu. br/>. Acesso em: 18 mar. 2017.

23 Ministério da Educação. Educaçáo superior. Disponível em: <http://portal.mec.gov.br/buscageral/212-noticias/educacao-superior-1690610854/46141-universidade-gaucha-oferecera-formacao-paraos-refugiados>. Acesso em: 17 mar. 2017 
equivalente no país onde residiam, tenham sido impossibilitados de dar continuidade ao ensino técnico ou superior pelo motivo de imigração ou que já tenham concluído os estudos equivalentes e não tenham interesse na revalidação do diploma.

No que tange à educação exclusivamente dos refugiados no Rio Grande do Sul, a Associação Antônio Vieira (ASAV) ${ }^{24}$ financia aulas em escolas e aulas particulares, para as famílias solicitantes de refúgio que fazem parte do seu programa, visto que o reassentamento de refugiados é um tema central para a Companhia de Jesus.

Desde 2003, a Associação Antônio Vieira possui acordo com o ACNUR, visando à implementação do Programa Brasileiro de Reassentamento Solidário, que tem por objetivo ser um complemento ao sistema de proteçáo internacional ao refugiado, pois possibilita tanto a proteção legal e física, como a solução duradoura, oferecendo condiçôes básicas e necessárias para que as pessoas retomem a sua autonomia e a cidadania, reiniciando, assim, suas vidas. Após a instalação das famílias em localidades do interior, por acreditar que nestes locais a rede pública de saúde e de acolhimento é mais eficaz, as crianças são matriculadas em escolas locais e as famílias recebem aulas particulares para ensino de português, custeadas pelo programa de reassentamento da ASAV, que é financiado pelo ACNUR.

Segundo Karin Wapechowski, coordenadora do programa, é imprescindível a implementação de políticas públicas de formação profissionalizante para refugiados, principalmente voltadas para a capacitaçáo de mulheres, uma vez que em suas regiốes de origem não obtiveram, por falta de oportunidade ou por força cultural, a oportunidade de receber estudos dirigidos para sua inserção no mercado de trabalho.

Além do trabalho realizado no acolhimento do refugiado, a ASAV realiza palestras para professores da rede pública e agentes estaduais e municipais que venham a trabalhar com a temática dos refugiados. Destaca Wapechowski:

Não somente as diversidades culturais devem ser consideradas, mas os traços psicológicos que são resultado da situação em que os refugiados foram expostos. Este contexto deve

\footnotetext{
24 Para a produçấo do artigo, foi realizada entrevista com a Sra. Karin Wapechowshi, coordenadora do Programa Brasileiro de Reassentamento Solidário de Refugiados da Associação Antônio Vieira no Rio Grande do Sul. Porto Alegre, 17 mar. 2017. Informação verbal.
} 
ser apreendido e considerado pelo educador e por todos os agentes públicos envolvidos. A rede de acolhimento do Rio Grande do Sul, conta ainda com o Núcleo de Defesa dos Direitos Humanos da Defensoria Pública do Estado do Rio Grande do Sul (DPERS) através do trabalho do Centro de Referência em Direitos Humanos (CRDH) da DPE, 25 onde há atendimento multidisciplinar a migrantes e refugiados nas áreas de competência da instituiçáo, sendo mais comuns as demandas em saúde, direito do consumidor, defesa criminal e validação de diplomas, entre outras.

A Universidade Federal do Rio Grande do Sul atua através do Grupo de Assessoria a Imigrantes e a Refugiados (Gaire-UFRGS) ${ }^{26}$, que desenvolve um projeto de extensão, vinculado ao Serviço de Assessoria Jurídica Universitária da UFRGS (Saju). Devido a interdisciplinaridade, o trabalho ali desenvolvido é multiprofissional, contando com estudantes de diferentes áreas, entre elas, Psicologia, Direito e Geografia.

Já o Ministério Público do Trabalho (MPT) ${ }^{27}$, tem suas açôes centradas no campo da investigação de irregularidades nas relaçôes de trabalho no âmbito coletivo, buscando sua resolução e ajuste, visto que a primeira ação de um migrante quando chega ao país é buscar trabalho, uma situação que pode gerar uma série de problemas, entre eles, o preconceito, a incompreensão e condiçôes análogas à de trabalho escravo.

O Ministério Público Federal ${ }^{28}$ atua na defesa de direitos constitucionais de brasileiros e estrangeiros e, mais comumente nas demandas coletivas, com destaque para a Procuradoria dos Direitos do Cidadâo, segmento que tem mais relaçấo com as questôes da população de migrantes e refugiados.

Muito também tem sido realizado pela Defensoria Pública da União nos casos individuais de refugiados e imigrantes, realizando açôes para garantir que esses grupos não sejam estigmatizados. Para tal, promove a sua inclusão nas políticas públicas brasileiras em igualdade de condiçóes com os cidadãos nacionais visando concretizar uma integraçâo local no país de acolhimento. Cabe destacar a criação do serviço multilíngue e multidisciplinar para atendimentos a refugiados e imigrantes oferecido todas as sextas-feiras e cuja atuação foi reconhecida pelo ACNUR como exemplo

\footnotetext{
25 Núcleo de Defesa dos Direitos Humanos - NUDDH - DPE/RS. Disponível em: <http://www. defensoria.rs.def.br/conteudo/20577>. Acesso em: 20 mar. 2017.

26 UFRGS/GAIRE - Grupo de assessoria a imigrantes e a refugiados. Disponível em: < http://www.ufrgs.br/ saju/grupos/gaire>. Acesso em: 22 mar. 2017.

27 Ministério Público Federal. Disponível em: <www.mpf.mp.br/>. Acesso em: 14 jan. 2017.

28 Ministério Público do Trabalho. Disponível em: <http://www.prt4.mpt.mp.br/>. Acesso em: 24
} fev. 2017. 
de boa prática institucional ${ }^{29}$.

Conforme constata-se por meio dos dados coletados e das entrevistas, os refugiados contam com um apoio maior do que aquele encontrado pelos que decidem imigrar para o Brasil. Neste contexto, apesar do aparente apoio governamental encontrado no grande número de acordos e leis, nenhuma das duas organizaçóes, CIBAI e ASAV, recebem recursos federais, sendo subsidiadas por organismos internacionais e pelo voluntariado.

A rede de acolhida, da qual participam vários órgãos do governo, ainda é motivada pelas levas ocasionais de imigrantes e refugiados e não pelo estabelecimento de um planejamento de acolhimento integrado e multidisciplinar com atuaçâo de profissionais preparados para atender às necessidades específicas deste tipo de contexto assistencial.

Mais especificamente, nas ações voltadas ao ensino de português pelo PRONATEC, é importante analisar se o quantitativo de refugiados que necessita deste tipo de curso é atendido, uma vez que os números informados pelo CONARE, em torno de 360 vagas, em 2016, não parecem atender a demanda anual de refugiados e solicitantes de refúgio.

\section{EDUCAÇÃO PARA A CIDADANIA E INCLUSÁO}

Foi na construção da democracia no Brasil que surgiu a necessidade do resgate dos direitos civis e políticos e o ensino destes direitos para a maioria da populaçẫo. A pedagogia de Paulo Freire ${ }^{30}$ é uma das influências decisivas nesse processo, que procura uma conscientização das pessoas através da educação, ou seja, a educação compreendida como uma prática libertadora. Portanto, é na evolução da construção da sociedade brasileira que esta concepção de educação em direitos humanos se amplia, para englobar outras dimensóes para além da participação política, da liberdade de expressão, do direito ao voto e dos demais direitos civis e políticos.

29 Maiores informaçôes, estão disponíveis no sítio: <http://www.dpu.def.br/noticias-rio-grande-dosul/152-noticias-rs-slideshow/31652-porto-alegre-e-reconhecida-como-cidade-solidaria-de-acolhimento-arefugiados $>$. Acesso em: 10 mar. 2017.

30 FREIRE, P. Pedagogia da indignaçáo: cartas pedagógicas e outros escritos, 2000, p.63. 
Segundo estudos da pedagoga Vera Candau ${ }^{31}$, depreende-se que a educação em direitos humanos no país é um processo sistemático, interdisciplinar e multidimensional orientado à formação de sujeitos de direitos e à promoçáo de uma cidadania ativa e participativa. A educaçáo é realizada pela articulaçáo de diferentes atividades que desenvolvem conhecimentos, atitudes, sentimentos e práticas sociais e que afirmam uma cultura de direitos humanos na escola e na sociedade. Visa ao desenvolvimento da consciência da dignidade humana de cada pessoa, orientando a formação do sujeito de direito e articulando as dimensôes sobre direitos humanos, a afirmação de valores, atitudes e práticas sociais que expressem uma consciência cidadã capaz de se fazer presente nos planos: sociais, éticos e políticos, e que expressem o fortalecimento de práticas individuais e sociais geradoras de ações e instrumentos a favor da promoção, da proteçáo e da defesa dos direitos humanos, assim como da reparação de suas violações.

A educadora Nancy Flowers ${ }^{32}$, distingue três tipos de definições de educação em direitos humanos segundo os agentes implicados: as agências governamentais, as organizaçôes não governamentais (ONGs) e os intelectuais universitários e educadores:

As organizaçôes governamentais colocariam ênfase na valorização de objetivos e resultados, especialmente os que preservem a ordem e o próprio Estado, ou seja, enfatiza o aspecto "direitos" dos direitos humanos, relacionando o tema à promoção da paz, a coesão, a ordem social, em oposiçáo a comportamentos e atitudes perturbadoras dessa mesma ordem, sendo responsabilidade dos governos buscar para que a educação em direitos humanos seja realizada adequadamente. As definições formuladas pelas organizações não governamentais também enfatizam resultados, mas com enfoques diferentes, pois ressaltam o aspecto "educação" da educação em direitos humanos. No terceiro bloco, temos os agentes implicados na definição do tema, os educadores e intelectuais, que tendem a mudar a ênfase para os valores que constroem e informam os processos de educação em direitos humanos. Para este grupo, a palavra mais importante na definição seria: "humano". Ainda que estas colocaçôes sejam interessantes na abordagem do tema, na prática, as açôes não têm sido individualizadas.

O que se constata no desenvolvimento de açôes voltadas à resolução das questôes que demandam da sociedade, é a presença de diferentes agentes sociais: agências internacionais,

31 CANDAU, V. M. F. Educação em direitos humanos: questôes pedagógicas. In: BITTAR, E. C. B. (Coord.). Educaçáo e Metodologia para os Direitos Humanos. 2008. pp. 285-298.

32 FLOWERS, N. How to Define Human Rigths Education? In: GEORGI, V.; SEBERICH, M.

(Eds.). International Perspectives in Human Rights Education,2004, p. 26. 
instituiçóes governamentais, ONGs, educadores e intelectuais, que, em parceria ou em iniciativas conjuntas e mistas, interagem continuamente entre a esfera governamental e o contexto social.

\subsection{O papel da Defensoria Pública da Uniáo na educaçáo em direitos, voltada ao empoderamento do imigrante e do refugiado como fator definitivo para o seu real acolhimento.}

A palavra empoderamento tem sua versão original do termo em inglês, empowerment, que conforme o dicionário Merriam-Webster traz as seguintes definiçôes: "1. to give official authority or legal power to. 2. enable. 3. to promote the self-actualization or influence of", ou seja, "1. ceder autoridade oficial a, ou poder legal. 2. habilitar. 3. promover a auto-atualização ou influência de" ${ }^{\prime 33}$.

Desta maneira, a palavra empoderamento é descrita na língua portuguesa, conceituando o ato ou efeito de promover conscientização e tomada de poder de influência de uma pessoa ou grupo social, geralmente para realizar mudanças de ordem social, política, econômica e cultural no contexto que lhe afeta, no sentido de dar a alguém ou a um grupo o poder de decisão em vez de tutelá-lo. Dessa forma, resgata um conceito que se encaixa perfeitamente na concepção de educação em direitos.

Com a finalidade de demonstrar o papel da Defensoria Pública da Uniáo, no contexto da educação em direitos, buscamos o regramento contido na Lei Complementar nacional no . $132 / 09$, nos artigos $1^{\circ}$. e $4^{\circ}$.:

Art. 1 A Defensoria Pública é instituição permanente, essencial à função jurisdicional do Estado, incumbindo-lhe, como expressão e instrumento do regime democrático, fundamentalmente, a orientação jurídica, a promoção dos direitos humanos e a defesa, em todos os graus, judicial e extrajudicial, dos direitos individuais e coletivos, de forma integral e gratuita, aos necessitados, assim considerados na forma do inciso LXXIV do art. $5^{\circ}$ da Constituição Federal.

Art. $4^{\circ}$

I - prestar orientação jurídica e exercer a defesa dos necessitados, em todos os graus;

II - promover, prioritariamente, a solução extrajudicial dos litígios, visando à composição entre as pessoas em conflito de interesses, por meio de mediaçáo, conciliação, arbitragem e demais técnicas de composição e administração de conflitos;

III - promover a difusão e a conscientização dos direitos humanos,

33 MERRIAM-WEBSTER. Dicionário Inglês-Português. Disponível em: < https://www.merriamwebster.com/dictionary/empowerment>. Acesso em: 16 mar. 2017. Tradução livre da autora. 
da cidadania e do ordenamento jurídico.

Segundo afirma com propriedade o Defensor Público do estado de São Paulo, Dr. Gustavo Augusto Soares dos Reis ${ }^{34}$, a palavra expressáo no artigo $1^{\circ}$ remete ao conceito de uma Defensoria Pública que se apresenta como um instrumento de Democracia, sendo que a manifestação da propriedade de acesso à justiça é uma das competências da educação em direitos.

Cabe ressaltar algumas diferenças entre o conceito de orientaçáo jurídica, relativa ao artigo $4^{\circ}$, inciso I, e educação em direitos, como ressalta Dos Reis:

A orientação jurídica é um discurso que enfatiza a dogmática, onde o defensor atua como agente de aconselhamento jurídico e como técnico para a solução de controvérsia. Aqui, assim, cabe ao defensor agir como um profissional que, diante de uma situação-problema (que não necessariamente seja litígio), esclarece para a pessoa (o assistido) a melhor solução jurídica para o seu caso. (...) A orientação jurídica, assim, é casuística - pois que abordada em um contexto de situação -problema - e possui tripla função: prevenir conflitos ou solucioná-los pacificamente, ou encorajar o litígio mediante a jurisdição.

Contudo, para que se atinja a pretensão de buscar um direito, primeiramente é necessário reconhecer a existência de um direito que possa ser juridicamente demandado. Ou seja, a educação em direitos é uma ação preventiva de conflitos e de demandas judiciais, atendendo aos objetivos expressos no artigo $4^{\circ}$, inciso II.

E, no sentido de promover a difusão e a conscientizaçáo dos direitos humanos, da cidadania e do ordenamento jurídico, conforme regrado pelo artigo $4^{\circ}$. inciso III, o mais adequado é previamente educar a sociedade para que aja como uma atitude pró-ativa em defesa dos seus direitos. A educação em direitos, como fator de empoderamento da população é algo inegável, e dentro do contexto dos imigrantes e refugiados este elemento atua náo somente na igualdade de direitos, mas como promotor da inserçáo social.

A servidora Laura Fernanda Zacher ${ }^{35}$, socióloga da Defensoria Pública da Uniăo em Porto

34 DOS REIS, G. A. S. Educação em Direitos e Defensoria Pública: Reflexôes a Partir da Lei Complementar n. 132/09. In: Temas Aprofundados da Defensoria Pública, Volume I, Jus Podivm, 2a Edição, Salvador, 2014.

35 Para a realização deste artigo foi entrevistada a socióloga e servidora da DPU/RS, Laura Fernanda Zacher, sobre a atuação da Defensoria Pública da União em Porto Alegre nos casos de imigrantes e refugiados. Porto Alegre, 16 mar. 2017. Informação verbal. 
Alegre, ressalta que é importante informar aos imigrantes e refugiados que a Defensoria Pública da União atua de forma autônoma na defesa dos direitos dos assistidos, não sendo a única forma na defesa de direitos. Assim, suas demandas podem ser ajuizadas e orientadas por outras vias, como a atuaçáo do Gaire-UFRGS, por exemplo.

Entre as várias açóes relevantes realizadas pela Defensoria Pública da União em relação à promoção dos direitos de imigrantes e refugiados, cabe citar algumas que ocorreram entre 2013 e 2016, entre as quais a participação da instituição na 1a Conferência Nacional sobre Migraçóes e Refúgio - COMIGRAR, coordenada pelo Ministério da Justiça, por meio da Secretaria Nacional de Justiça/Departamento de Estrangeiros, em parceria com os Ministérios do Trabalho e das Relaçôes Exteriores, com o apoio da Organização Internacional para as Migraçóes e Programa das Naçóes Unidas para o Desenvolvimento (PNUD). O objetivo da conferência era promover uma reflexão coletiva e definir propostas para a construção da Política e do Plano Nacionais de Migraçóes e Refúgio. Foi realizada junto da COMIGRAR, através de uma conferência virtual interna, objetivando discutir a temática e enviar propostas para subsidiar a política migratória nacional com base nos Direitos Humanos, entre elas: a isenção de taxas para emissáo de documentos e não cobrança de multas e gratuidade dos demais atos necessários para estrangeiros hipossuficientes; a possibilidade de prorrogação e emissão de visto dentro do território brasileiro, sem necessidade de retorno ao país de origem para solicitá-lo; e a criação de centros de referência para atenção à população presa e egressa estrangeira.

Zacher cita ainda as ações de recomendaçáo para a retirada da palavra refugiado da Carteira de Identidade de Estrangeiro - (CIE), que gerava estigmatização do grupo, substituindo pela indicação "Amparado pela Lei no 9.474/97", que é a lei de Refúgio no Brasil. Por meio de uma recomendação feita à Polícia Federal pelo Ofício de Direitos Humanos e Tutela Coletiva da Defensoria Pública da União em Porto Alegre, os estrangeiros refugiados no Brasil terão o termo refugiado retirado de sua carteira de identificação ${ }^{36}$, e a intermediação entre Prefeitura de Porto Alegre e Ministério da Justiça para criação do Centro de Referência e Acolhida para Migrantes e Refugiados em Porto Alegre, que prevê abrigo emergencial de 50 imigrantes e visa ao oferecimento do espaço adequado para abrigar, refugiados, imigrantes e solicitantes de refúgio, além de promover a integração social e garantir direito à alimentação, acesso à saúde, proteção social, intermediação para o trabalho e capacitação profissional, ensino de língua portuguesa, orientação jurídica

36 Maiores informaçôes disponíveis em: <http://www.dpu.def.br/noticias-defensoria-publica-dauniao/16374-termo-refugiado-sera-retirado-da-carteira-de-identidade-de-estrangeiro $>$. Acesso em: 05 mar. 2017. 
sobre direitos e obrigações no país, entre outras ações.

\section{CONSIDERAÇÓES FINAIS}

O perfil imigratório brasileiro, que se mantinha em levas ocasionais ao longo da história, desde a sua colonização até a segunda metade do século XX, experimentou considerável crescimento em decorrência da estabilidade econômica verificada no país a partir do início dos anos 2000. Este movimento foi resultado do posicionamento do Brasil entre as maiores potências econômicas do planeta, chegando a figurar, em determinados momentos, na sexta economia mundial. Esta fase histórica força o país a assumir, novamente, um perfil acolhedor, devido ao considerável aumento do ingresso de trabalhadores imigrantes em seu território, originários, principalmente, do Haiti, da Venezuela e de países do continente africano.

Breve e sucintamente, nosso objetivo neste trabalho, foi demonstrar os fluxos de imigrantes que formaram historicamente o Brasil e o Rio Grande do Sul e que se destacaram graças a sua capacidade de trabalho, disciplina e multiplicidade cultural, agregando valor à cultura gaúcha. Não obstante, devido ao fator de envelhecimento da população, particularmente sensível no Rio Grande do Sul, e a carência de profissionais de diversas áreas, especialmente em regiôes mais isoladas do estado, a questão do reduzido suprimento dos postos de trabalho tornou-se um fator determinante para a sensibilização do empresariado à abertura de oportunidades para a atuaçáo dos imigrantes e refugiados no mercado de trabalho, embora ainda persistam alguns preconceitos com relação às distinçôes culturais e religiosas de alguns grupos.

Apesar do mito de ser um país acolhedor, o Brasil apresenta ainda uma populaçáo com visão difusa em relação a possível ameaça de competição por postos de trabalho que os estrangeiros viriam a ocupar em detrimento dos trabalhadores locais.

O objetivo principal dos imigrantes que aportam no país é iniciar um novo processo de reconstrução de suas vidas, encontrar um trabalho capaz de atender suas expectativas e que lhes permita ter condiçóes mínimas de subsistência para si e seus familiares, que, na maioria das vezes, permanecem em seus países de origem.

Dessa forma, políticas públicas educacionais, voltadas ao ensino de português, educação em direitos e formação profissional são fatores primordiais para o estabelecimento inicial 
deste processo. As respostas de Políticas Públicas aos desafios das migraçôes e do refúgio devem ser: transdisciplinares, integradas, multiculturais e contextualizadas, capazes de reconhecer e assumir a complexidade que o tema requer.

Cabe ao Estado brasileiro desenvolver políticas capazes de atender às demandas e expectativas destes trabalhadores, a fim de que sejam oferecidas a estes as condiçóes mínimas para o estabelecimento de uma vida digna em território nacional, conforme o desejo expresso pelos constituintes, no artigo 5º da Constituição da República de 1988, que garante aos estrangeiros residentes no país os mesmos direitos e deveres individuais e coletivos assegurados aos brasileiros natos.

Engajados na mudança de paradigma para o acolhimento e valorizaçáo do capital social e cultural, instituiçóes como a Defensoria Pública da Uniâo, vem fortalecendo os vínculos da rede de acolhida, apoiando e promovendo a educaçáo em direitos aos refugiados e aos imigrantes, sempre lutando para oferecer o tratamento adequado a este segmento crescente, através de iniciativas inovadoras como o serviço de atendimento multilíngue.

Além disso, a Defensoria Pública da União vem atuando como instrumento democrático para a mudança de postura da população face à recepção de novos imigrantes e refugiados, com vistas ao reconhecimento e valorização da contribuiçáo histórica e cultural que a imigração estrangeira pode agregar para o desenvolvimento sócio-econômico da sociedade gaúcha e, sobretudo, para a formação da sociedade brasileira.

\section{REFERENCIAS}

ACNUR. Convençáo relativa ao Estatuto dos Refugiados. Disponível em: <http:// www.acnur.org/t3/fileadmin/Documentos/portugues/BDL/Convencao_relativa_ao_ Estatuto_dos_Refugiados.pdf>. Acesso em: 23 mar. 2017.

Declaraçáo de Cartagena. Disponível em: <http://www.acnur.org/t3/ fileadmin/Documentos/portugues/BD_Legal/Instrumentos_Internacionais/Declaracao_ de_Cartagena.pdf $>$. Acesso em: 23 mar. 2017.

. Tendências Globais - 2016. Disponível em: <http://www.unhcr. org/576408cd7>. Acesso em: 23 mar. 2017. 
Estatísticas 2016. Disponível em: <http://www.acnur.org/portugues/recursos/ estatisticas/>. Acesso em 20 mar.2017.

Pode Entrar: Português do Brasil para refugiadas e refugiados. 2015. Disponível em: <http://www.acnur.org/portugues/recursos/publicacoes/>. Acesso 20 mar. 2017.

Deslocamento forçado atinge recorde global e afeta uma em cada 113 pessoas no mundo. Disponível em: <http://www.acnur.org/portugues/noticias/noticia/ deslocamento-forcado-atinge-recorde-global-e-afeta-uma-em-cada-113-pessoas-nomundo/>. Acesso em 23 mar.2017

BERGSON, H. A evoluçáo criadora. In: Cartas, conferências e outros escritos. São Paulo, Abril Cultural, 1979. p.153-205.

BRANCO, I. C. Os novos trabalhadores imigrantes: o "sonho brasileiro". Panorama Internacional: Volume I, no. 3, 2016. Disponível em: <http://panoramainternacional.fee.tche. br/article/os-novos-trabalhadores-imigrantes-o-sonho-brasileiro/>. Acesso em: 10 mar. 2017.

BRASIL. Constituiçẫo (1988). Constituiçâo: República Federativa do Brasil. Brasília, DF: Senado Federal, 1988.

. Constituição (1937). Constituiçáo: República Federativa do Brasil. Brasília, DF: Senado Federal, 1937.

Lei Complementar No 132, de 7 de outubro de 2009. Altera dispositivos da Lei Complementar No 80, de 12 de janeiro de 1994. Disponível em: <http://www.planalto.gov.br/ ccivil_03/leis/lcp/lcp132.htm>. Acesso em: 18 mar. 2017.

. Lei Ordinária No 9.474, de julho de 1997. Define mecanismos para a implementaçáo do Estatuto dos Refugiados de 1951, e determina outras providências. Disponível em: <http:// www.planalto.gov.br/ccivil_03/leis/L9474.htm>. Acesso em: 09 mar. 2017.

Ministério da Educaçáo. Educação superior. Disponível em: <http://portal.mec. gov.br/busca-geral/212-noticias/educacao-superior-1690610854/46141-universidade-gauchaoferecera-formacao-para-os-refugiados>. Acesso em: 17 mar. 2017.

. Ministério da Educação. PRONATEC. Disponível em: <http://portal.mec.gov.br/ 
pronatec/cursos-pronatec>. Acesso em: 19 mar. 2017.

Ministério da Justiça. CONARE. Sistema de Refúgio brasileiro: desafios e perspectivas. Disponível em: <http://csem.org.br/index.php/estatisticas/4635-sistema-derefugio-brasileiro >. Acesso em: 15 mar. 2017.

Ministério do Trabalho e Previdência Social. Coordenação Geral de Imigração do Ministério do Trabalho e Previdência Social. Disponível em: <http://acesso.mte.gov.br/obmigra/ relatorio-anual/>. Acesso em: 18 dez. 2016.

.Ministério do Trabalho e Previdência Social. Conselho Nacional de Imigração. Disponível em:< http://trabalho.gov.br/dados-abertos/trabalho-estrangeiro/estatisticasimigracao/conselho-nacional-de-imigracao-cnig>. Acesso em 18 mar. 2017.

.Ministério do Trabalho e Previdência Social. Dados estatísticos. Disponível em:<http://obmigra.mte.gov.br/index.php/relatorios-cgig-e-cnig>. Acesso em 10 jan. 2017.

.Ministério Público Federal. Disponível em: <www.mpf.mp.br/>. Acesso em: 14 jan. 2017.

.Ministério Público do Trabalho. Disponível em: <http://www.prt4.mpt.mp.br/>. Acesso em: 24 fev. 2017.

.Pacto Internacional de Direitos Econômicos, Sociais e Culturais. Disponível em: <http://www.planalto.gov.br/ccivil_03/decreto/1990-1994/d0591.htm>. Acesso em: 13 mar. 2017.

CANDAU, V. Educaçáo em direitos humanos: questôes pedagógicas. In: BITTAR, Eduardo (coord.). Educação e metodologia para os direitos humanos. São Paulo: Quartier Latin, 2008.

CARNEIRO, M. L. T. A imagem do imigrante indesejável. São Paulo, 2003.

DEFENSORIA PÚBLICA DA UNIÃO. Acesso à informaçáo. Porto Alegre, 2013. Disponível em: <http://www.dpu.def.br/noticias-defensoria-publica-da-uniao/16374-termorefugiado-sera-retirado-da-carteira-de-identidade-de-estrangeiro>. Acesso em: 05 mar. 2017.

Acesso à informaçáo. Porto Alegre, 2016. Disponível em: :<http://www.dpu.def. 
br/noticias-rio-grande-do-sul/152-noticias-rs-slideshow/31652-porto-alegre-e-reconhecidacomo-cidade-solidaria-de-acolhimento-a-refugiados>. Acesso em: 10 mar. 2017.

.Acesso à informaçáo. Brasília, 2016. Disponível em: <http://www.dpu.def.br/noticiasdefensoria-publica-da-uniao/68-noticias-internacional/35840-cnig-adota-recomendacao-dadpu-e-autoriza-residencia-para-venezuelanos>. Acesso em: 24 de mar. 2017.

DEFENSORIA PÚBLICA DO ESTADO DO RIO GRANDE DO SUL. Núcleo de Defesa dos Direitos Humanos - NUDDH. Disponível em:<http://www.defensoria.rs.def.br/ conteudo/20577>. Acesso em: 20 mar. 2017.

DOS REIS, G. A. S. Educaçáo em Direitos e Defensoria Pública: Reflexôes a Partir da Lei Complementar n. 132/09, in Temas Aprofundados da Defensoria Pública, Volume I, Jus Podivm, $2^{\text {a }}$ Edição, Salvador, 2014.

IFRS. Curso de Português como Língua Estrangeira: parte I e parte II. Disponível em: <https:// moodle.ifrs.edu.br/>. Acesso em: 18 mar. 2017.

FLOWERS, N. How to Define Human Rigths Education? In: GEORGI, Viola; SEBERICH, Michael. (Eds.). International Perspectives in Human Rights Education. Alemanha: Bertelsmann Foundation Publishers, 2004.

FREIRE, P. Pedagogia da indignação: cartas pedagógicas e outros escritos. São Paulo: Unesp, 2000.

MARX, K.; ENGELS, F. La ideologia alemana. Montevideo, Pueblos Unidos, 1974.

MERRIAM-WEBSTER. Dicionário Inglês-Português. Disponível em: <https://www.merriamwebster.com/ dictionary/empowerment>. Acesso em: 16 mar. 2017.

UEBEL, R. R. G. Análise do perfil socioespacial das migraçóes internacionais para o Rio Grande do Sul no início do século XXI: redes, atores e cenários da imigração haitiana e senegalesa. Programa de Pós-Graduação em Geografia. Porto Alegre, UFRGS, 2015. Disponível em: <http://hdl.handle. net/10183/117357. Acesso em: 15 mar. 2017.

O Brasil na agenda global das migraçóes internacionais: inserçáo estratégica ou ciclos migratórios? 1o Seminário Internacional de Ciência Política: Estado e Democracia em mudança no século XXI, Porto Alegre, 2015. 
UNIVERSIDADE FEDERAL DO RIO GRANDE DO SUL. GAIRE - Grupo de assessoria a imigrantes e a refugiados. Disponível em: <http://www.ufrgs.br/saju/ grupos/gaire>. Acesso em: 22 mar. 2017.

ZAMBERLAM, J., et al. Os novos rostos da imigraçáo no Brasil: haitianos no Rio Grande do Sul. Ed. Sólidos, Porto Alegre, 2014. 